\title{
MODELING OF WATER QUALITY INDEX OF SHAHANUR RIVER OF \\ ANJANGAON SURJI REGION IN MAHARASHTRA STATE
}

\author{
P. P. Bhatkar \\ Assistant Proffessor, Smt. Radhabai Sarda College, \\ Anjangaon Surji \\ Email- preranabhatkar1@gail.com, Mob-8055259809
}

\begin{abstract}
The present study was undertaken to assess the water quality of River Shahanur of Anjangaon Surji region, Amravati district in Maharashtra. For the analysis of water quality, various physico chemical parameters are tested and analyzed by Water Quality Index. According to Water Quality Index model, water quality of Shahanur River is good for all sites by aggregative method. But as per multiplicative method, it is medium for all the sites. According to the water quality index of water, quality of water of sites 1 to 9 is moderate, which is not fit for drinking, even though it can be supplied for 225 villages and 2 towns having a population of about 5,00,000. The quality of water can be used for bathing and other domestic purposes only.
\end{abstract}

Keywords - waterquality index,WQI, Physico-chemical parameter

\section{Introduction}

India is land of river having about 500 rivers in the country including 14 international rivers. From ancient times, India is known as "Sapta Sindhus Pradesh" means India's socioeconomic, cultural development took place in the region of rivers. River water is main source in India for all the domestic purposes. But with the advancement of civilization, the utility of water has enormously increased. Thus, it is necessary for all countries to build dam on the rivers. Shahanur dam was one of the dams built to supply fresh water for all domestic purposes, electricity generation and irrigation.

River Shahanur is one of important rivers of Vidarbha Region in Maharashtra State. River Shahanur originates near the village Vairat in the proximity of Chikhaldara, Amravati district in Maharashtra. The dam site for Shahanur project is located at latitude $21^{\circ} 15^{\prime} 21^{\prime \prime}$ and longitude $77^{\circ} 19^{\prime} 30^{\prime \prime}$. Shahanur dam is an earthen dam constructed 
across the Shahanur River. The total catchment area up to the dam site is 53.74 sq. miles $\left(139.187 \mathrm{Km}^{2}\right)$. Water stored in the Shahanur dam is supplied daily to 225 villages and 2 towns having a population of about $5,00,000$. The main important thing is that for all this purposes gravitation force is applied without any consumption of electricity. This gravitational based Water supply system is only one of its kind in India, which is recorded in Limca book of record.

\section{Aims and Objectives}

1. Monitoring of Shahanur River in $15 \mathrm{Kms}$ stretch.

2. Selection of various sampling points.

3. Bio Chemical characterization of sample water.

4. Development of mathematical model for comparing the data.

5. Analyze the obtained data with the help of Water Quality Index Model

\section{Material and Methods}

For qualitative assessment of Shahanur river water, a $15 \mathrm{~km}$ stretch was selected between the entire stretch of the river and its basin. Nine sampling stations were selected upstream of the dam which is located at latitude $21^{\circ} 15^{\prime} 21^{\prime \prime}$ and at longitude $77^{\circ} 19^{\prime} 30^{\prime \prime}$.

For the determination water quality of the Shahanur River, monthly monitoring of water quality at selected stations for a period of two years during May 2007 to April 2009 was done.

Sampling was done once in a month. The climate of the site is continental. It is hot and dry in summer, mild in winter, cloudy and rainy in rainy season. The entire chemicals used in the study were of analytical grade. Double distilled water was used throughout the study. All glass wares and sample containers were thoroughly cleaned and finally rinsed with double distilled water. Standard Methods for the examination of water and waste water published by American Public Health Association (APHA 1989) and "Laboratory Manual on Water Analysis of NEERI" was used as well as "water and waste water for engineering" is used for water quality index. 
Temperature was measured by mercury thermometer. pH, EC, TDS and Salinity was measured by analytical mobile kit. DO was analyzed by the spot Iodometric with azid modification method. This also forms the basis for BOD estimation by incubation method using BOD incubator at $27^{\circ} \mathrm{C}$ for 3 days. The COD values were determined by refluxing the sample with mixture of standard potassium dichromate and concentrated sulphuric acid. The hardness estimated by the conventional EDTA titration method. Sulphate was analyzed by turbidity method using colorimeter. The amount of chloride ions was analyzed by argentometric method, which involves titration with standard $\mathrm{AgNO}_{3}$ solution using potassium chromate as an indicator. Sodium and Potassium was estimated by flame photometer. Bacteriological parameters, FC and TC were estimated through multiple dilution method. (MPN count).

\section{Observations}

From the collected data,Water Quality Indices are calculated. Observations of seasonal variation as well as Water Quality Index modeling are given in the Table 2

Calculation of Water Quality index

\begin{tabular}{|c|c|c|c|c|c|}
\hline \multicolumn{5}{|c|}{ Table no 1 Calculation of weights (Wi) } & Mean \\
\hline Parameters & $\begin{array}{c}\text { Actual } \\
\text { Rank }\end{array}$ & $\begin{array}{c}\text { Temp } \\
\text { Reight }\end{array}$ & $\begin{array}{c}\text { Sum of } \\
\text { temp }\end{array}$ & $\begin{array}{c}\text { Final } \\
\text { weight }\end{array}$ \\
\hline pH & 2 & 0.4 & 5 & weight & \\
\hline DO & 2 & 0.4 & 5 & 60 & 0.08 \\
\hline BOD & 1 & 0.4 & 2.5 & 60 & 0.08 \\
\hline COD & 3 & 0.4 & 7.5 & 60 & 0.13 \\
\hline Alkalinity & 3 & 0.4 & 7.5 & 60 & 0.13 \\
\hline C.Hardnes & 5 & 0.4 & 12.5 & 60 & 0.2 \\
\hline s & 4 & 0.4 & 10 & 60 & 0.17 \\
\hline TDS & 4 & 0.4 & 5 & 60 & 0.08 \\
\hline Turbidity & 2 & 0.4 & 2.5 & 60 & 0.04 \\
\hline FC & 1 & 0.4 & 2.5 & 60 & 0.04 \\
\hline TC & 1 & & & & \\
\hline
\end{tabular}

$6-$

$\mathrm{pH} \quad$ Sep

DO $0-9$

0 -

COD $\quad 300$

Alkalinit

y 200

C. Hard 0-

ness $\quad 600$

0 -

TDS $\quad 500$

Turbidit 0-

y 100

180

TC $\quad 400$ 


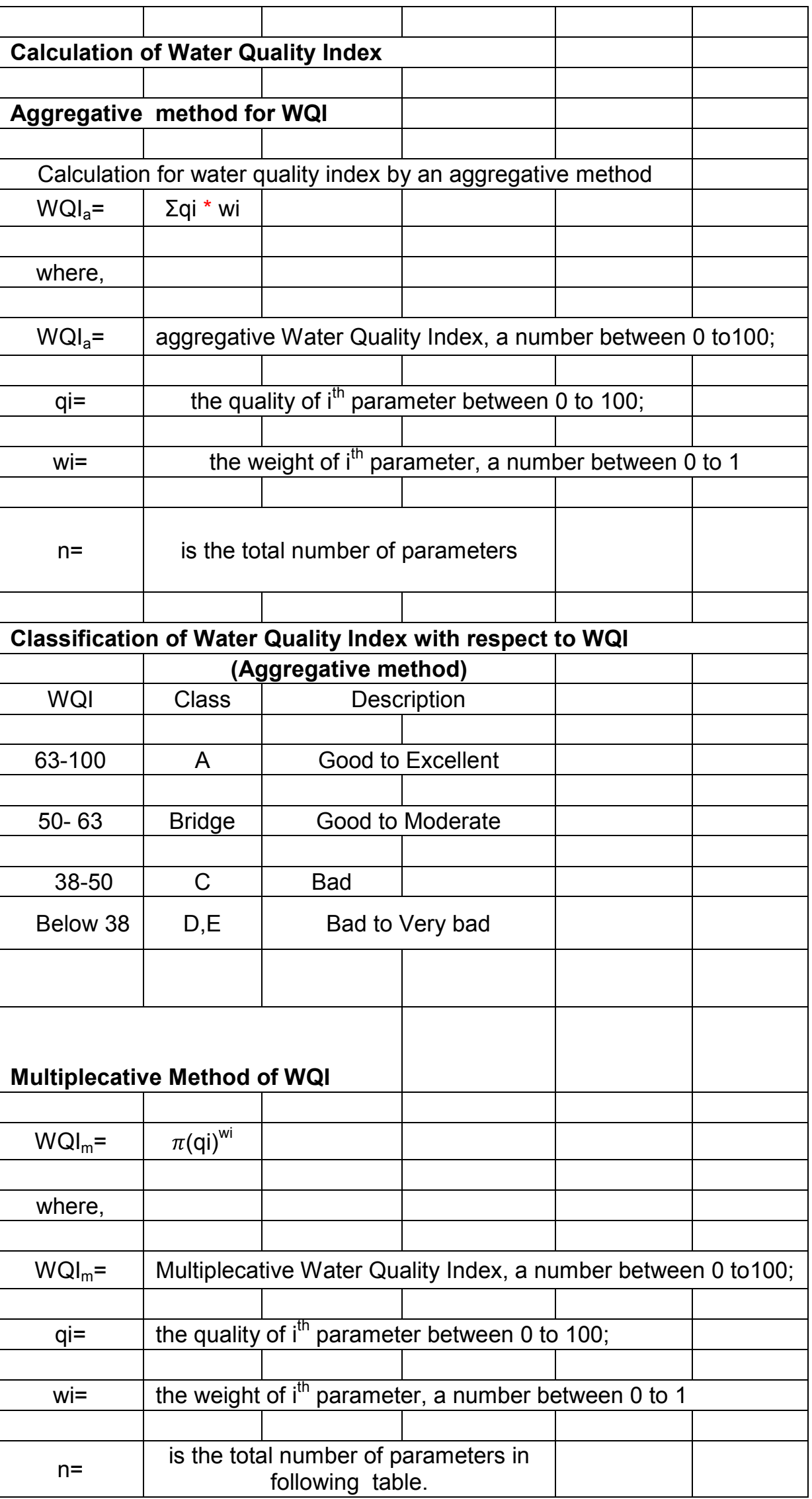




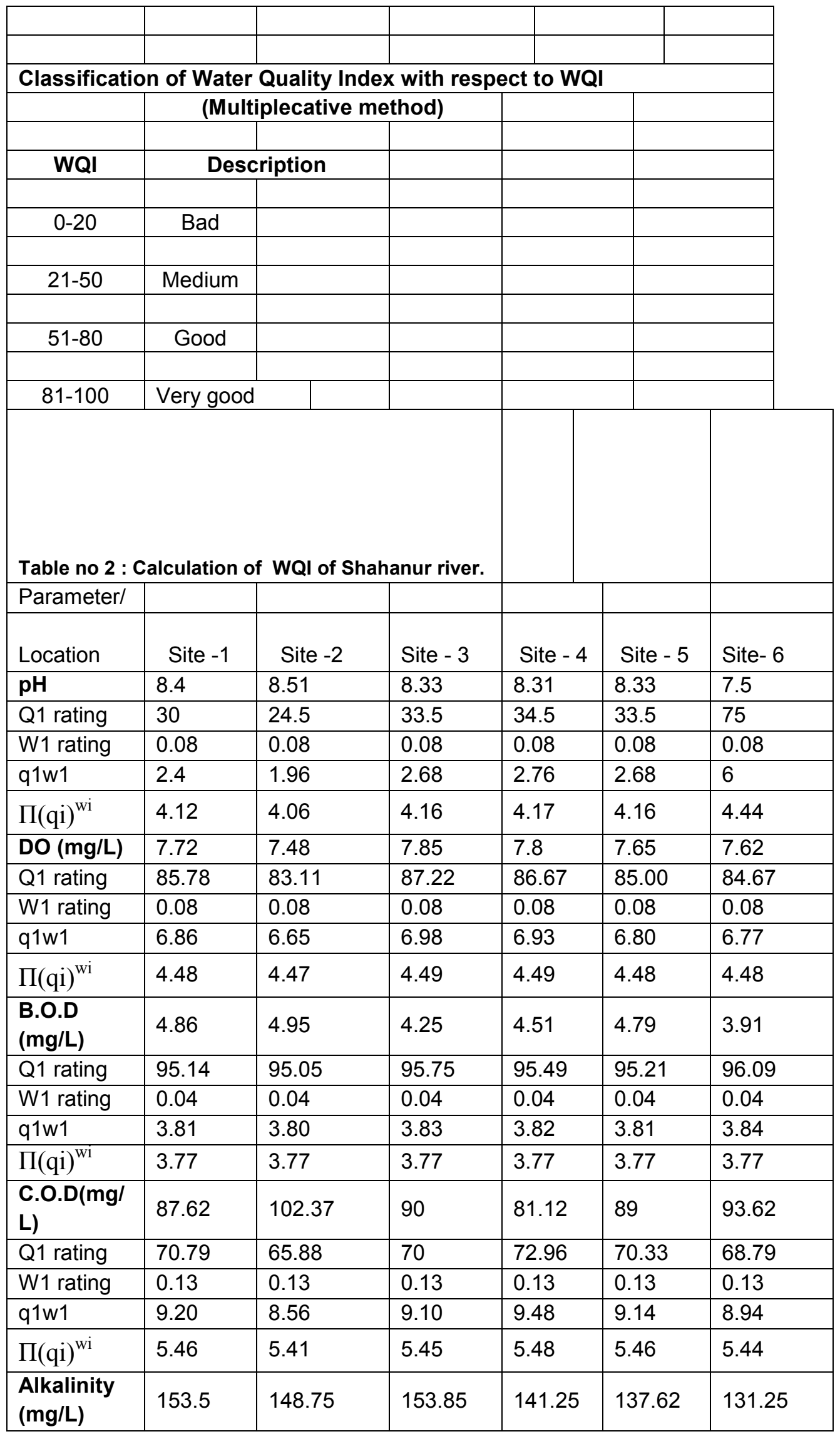




\begin{tabular}{|l|l|l|l|l|l|l|}
\hline Q1 rating & 23.25 & 25.625 & 23.075 & 29.375 & 31.19 & 34.375 \\
\hline W1 rating & 0.13 & 0.13 & 0.13 & 0.13 & 0.13 & 0.13 \\
\hline q1w1 & 3.02 & 3.33 & 3.00 & 3.82 & 4.05 & 4.47 \\
\hline$\Pi(q 1))^{\text {wi }}$ & 4.73 & 4.79 & 4.72 & 4.87 & 4.91 & 4.97 \\
\hline $\begin{array}{l}\text { C. } \\
\text { hardness }\end{array}$ & 98.75 & 105.87 & 113.87 & 93.25 & 92.25 & 90.62 \\
\hline (mg/L) $^{\text {Q1 rating }}$ & 83.54 & 82.36 & 81.02 & 84.46 & 84.63 & 84.90 \\
\hline W1 rating & 0.2 & 0.2 & 0.2 & 0.2 & 0.2 & 0.2 \\
\hline q1w1 & 16.71 & 16.47 & 16.20 & 16.89 & 16.93 & 16.98 \\
\hline$\Pi(q i){ }^{\text {wi }}$ & 7.61 & 7.59 & 7.56 & 7.63 & 7.63 & 7.63 \\
\hline
\end{tabular}

\begin{tabular}{|c|c|c|c|c|c|c|c|c|c|}
\hline $\begin{array}{l}\text { Parameter/ } \\
\text { Location }\end{array}$ & $\begin{array}{c}\text { Site - } \\
1 \\
\end{array}$ & $\begin{array}{c}\text { Site - } \\
2 \\
\end{array}$ & $\begin{array}{c}\text { Site - } \\
3 \\
\end{array}$ & $4^{\text {Site - }}$ & $5^{\text {Site - }}$ & Site- 6 & Site -7 & Site -8 & Site -9 \\
\hline TDS (mg/L) & 164.22 & 169.5 & 168.53 & 167.62 & 162.15 & 149.78 & 149.93 & 160.58 & 162.6 \\
\hline Q1 rating & 67.156 & 66.1 & 66.294 & 66.476 & 67.57 & 70.044 & 70.014 & 67.884 & 67.48 \\
\hline W1 rating & 0.17 & 0.17 & 0.17 & 0.17 & 0.17 & 0.17 & 0.17 & 0.17 & 0.17 \\
\hline q1w1 & 11.42 & 11.24 & 11.27 & 11.30 & 11.49 & 11.91 & 11.90 & 11.54 & 11.47 \\
\hline$\Pi(q i)^{w i}$ & 6.42 & 6.40 & 6.41 & 6.41 & 6.43 & 6.47 & 6.47 & 6.43 & 6.43 \\
\hline Turbidity (NTU) & 40.43 & 36.52 & 26.13 & 31.77 & 27.13 & 33.61 & 33.53 & 34.6 & 38.9 \\
\hline Q1 rating & 59.57 & 63.48 & 73.87 & 68.23 & 72.87 & 66.39 & 66.47 & 65.4 & 61.1 \\
\hline W1 rating & 0.08 & 0.08 & 0.08 & 0.08 & 0.08 & 0.08 & 0.08 & 0.08 & 0.08 \\
\hline $\mathrm{q} 1 \mathrm{w} 1$ & 4.77 & 5.08 & 5.91 & 5.46 & 5.83 & 5.31 & 5.32 & 5.23 & 4.89 \\
\hline$\Pi(q i)^{w i}$ & 4.35 & 4.38 & 4.43 & 4.40 & 4.43 & 4.39 & 4.39 & 4.39 & 4.36 \\
\hline $\begin{array}{l}\text { F.C (per } 100 \\
\text { ml) }\end{array}$ & 161.25 & 394.87 & 335.5 & 157.5 & 120.62 & 53.87 & 29.62 & 22.37 & 21.37 \\
\hline Q1 rating & 91.04 & 78.06 & 81.36 & 91.25 & 93.30 & 97.01 & 98.35 & 98.76 & 98.81 \\
\hline W1 rating & 0.04 & 0.04 & 0.04 & 0.04 & 0.04 & 0.04 & 0.04 & 0.04 & 0.04 \\
\hline q1w1 & 3.64 & 3.12 & 3.25 & 3.65 & 3.73 & 3.88 & 3.93 & 3.95 & 3.95 \\
\hline$\Pi(\mathrm{qi})^{\mathrm{wi}}$ & 3.76 & 3.74 & 3.74 & 3.76 & 3.76 & 3.77 & 3.77 & 3.77 & 3.77 \\
\hline $\begin{array}{l}\text { T.C ( per } 100 \\
\text { ml) }\end{array}$ & 87.12 & 73.62 & 92.62 & 68.78 & 47 & 31.37 & 18.87 & 15.87 & 13.12 \\
\hline Q1 rating & 78.22 & 81.60 & 76.85 & 82.81 & 88.25 & 92.16 & 95.28 & 96.03 & 96.72 \\
\hline W1 rating & 0.04 & 0.04 & 0.04 & 0.04 & 0.04 & 0.04 & 0.04 & 0.04 & 0.04 \\
\hline q1w1 & 3.13 & 3.26 & 3.07 & 3.31 & 3.53 & 3.69 & 3.81 & 3.84 & 3.87 \\
\hline$\Pi(\mathrm{qi})^{\mathrm{wi}}$ & 3.74 & 3.74 & 3.74 & 3.75 & 3.76 & 3.76 & 3.77 & 3.77 & 3.77 \\
\hline$W Q I=\Sigma q 1 w 1$ & 64.95 & 63.48 & 65.3 & 67.43 & 67.99 & 71.79 & 72.93 & 72.57 & 72.68 \\
\hline $\begin{array}{l}\text { WATER } \\
\text { QUALITY } \\
\end{array}$ & Good & Good & Good & Good & Good & Good & Good & Good & Good \\
\hline WQI $=\Sigma \Pi(q i) w i$ & 48.44 & 48.34 & 48.47 & 48.72 & 48.78 & 49.12 & 49.23 & 49.18 & 49.19 \\
\hline $\begin{array}{l}\text { WATER } \\
\text { QUALITY } \\
\end{array}$ & $\begin{array}{l}\text { Mediu } \\
\mathrm{m}\end{array}$ & $\begin{array}{l}\text { Mediu } \\
\mathrm{m}\end{array}$ & $\begin{array}{l}\text { Mediu } \\
\mathrm{m}\end{array}$ & $\begin{array}{l}\text { Mediu } \\
\mathrm{m}\end{array}$ & $\begin{array}{l}\text { Mediu } \\
\mathrm{m}\end{array}$ & $\begin{array}{l}\text { Mediu } \\
\mathrm{m}\end{array}$ & $\begin{array}{l}\text { Mediu } \\
\mathrm{m}\end{array}$ & $\begin{array}{l}\text { Mediu } \\
\mathrm{m}\end{array}$ & $\begin{array}{l}\text { Mediu } \\
\mathrm{m}\end{array}$ \\
\hline
\end{tabular}




\section{Results and Discussion}

The fecal and total coliform bacterial count in Shahanur river water was as low as 7 coliform per $100 \mathrm{ml}$ except 1600 coliform per $100 \mathrm{ml}$ in May i.e. during summer. This is because of the less water flowing in river during summer and more human activities. However throughout the year, the bacterial count was low and fluctuating. In India most of the holy river like Godavari, Ganges, Yamuna, have more fecal coliform count (Gautam 1990; Khanna and Bhutiyani; 2006).

The overall study of physio-chemical and microbial parameters of Shahanur rivers water reveals that the water quality is changing gradually due to certain anthropogenic activities in and in the vicinity of river. The agricultural run off may also be responsible for changing the water quality. If these activities are not banned at right time, the potability of water may be hampered in near future. Today also, it is recommended that the Shahanur river water should be used only after proper treatment. In fact public awareness has to be evolved to make people conscious of water pollution, in order to control the same.

\section{Conclusion}

According to Water Quality Index model, water quality of Shahnur River is good for all sites by aggregative method. As per multiplicative method, it is medium for all the sites. According to the water quality index of water, quality of water at sites $1,2,3,4,5,6,7,8$ and 9 are moderate, which is not fit for drinking, even though it is being supplied for 225 villages and 2 towns. The quality of water can be used for bathing and other domestic purposes only.

\section{Acknowledgement-}

The author expresses her deep sense of gratitude to Dr.S.S.Patil, Director of Student Welfare Society. S.G.B.University , Amravati(M.S.) for his invaluable guidance. encouragement, moral support and his keen interest throughout the course of her work. 
The Author is indebted to Dr.N.S.Ingole, Principal, IBSS, SGB, and Amravati University, Amravati for his encouragement and moral support and help rendered in the course of her work.

\section{References:}

B. Padmanabha and et.al. (Jan. 2007)

Water Quality Index of Kabini River the Kallahally Vallage of Nanjangud Taluk, Mysore District, Karnataka (India)

Gautam, A (1990)

Ecology and pollution of mountain river water, Ashish pub. House. N. Delhi.pp.206, Khanna, D.R.Bhutiani,R.(2006):Water analysis-At a Glance. ASEA PUBLICATION,PP1-116.

Metcaff and Eddy "Water and waste water engineering"

Veerabhadram (Arpil 2009) Mapping of water Quality Index. (WQI) using Geographical information System (GIS) As decision Supporting system Tool

http://www.gisdevelopment.net/application/environment/water/ma031 23abs.htm 